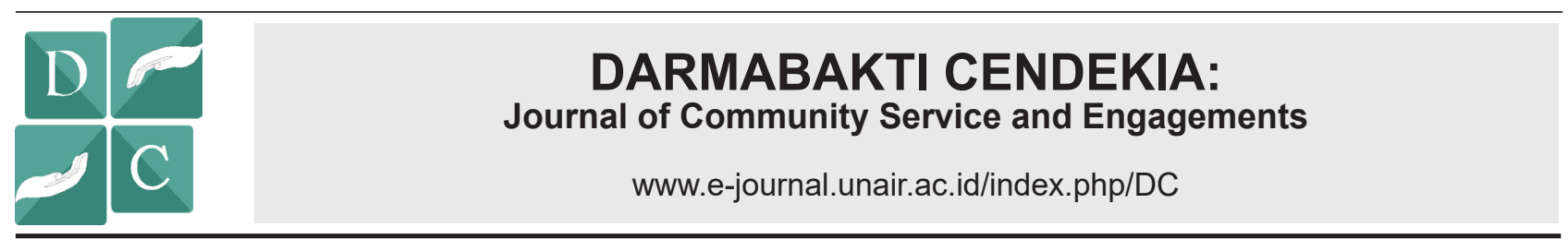

\section{EMPOWERING WOMEN OF BATIK COMMUNITY IN HEALTH IN KECAMATAN KEREK, TUBAN DISTRICT}

\author{
PEMBERDAYAAN PEREMPUAN KOMUNITAS BATIK DI BIDANG \\ KESEHATAN DI KECAMATAN KEREK, KABUPATEN TUBAN
}

\author{
Karnaji*, Emy Susant圆 Siti Masudah \\ Study Program of Sociology, Faculty of Vocational Studies, Universitas Airlangga, Surabaya-Indonesia
}

\section{A B S T R A C T}

Background: The economic contribution of women batik craftsmen in Tuban is relatively important in their families even though their income is below the district / city minimum wage (below the UMK). In general, women batik craftsmen in Tuban work as additional income earners, with flexible working hours that can be combined with domestic duties. Objective: This activity is to provide solutions to problems; a) Tuban batik handicraft and business is treated as a side job, not as a main job, so that it is not professionally in managing their business; b) women batik craftsmen in Tuban have social characteristics with low education and often live in economically poor conditions so that they are in a weak and vulnerable position from the socio-economic structure; c) the work welfare of women batik craftsmen in Tuban is not formally protected because batik production and business are located in a home environment which is considered as the informal sector; $d$ ) women who make Tuban batik have to play a 'multi burden' role. Methods: This activity is carried out in training and business management assistance. Results: The results of this activity are: 1) Increased awareness of women batik craftsmen for their strategic role in economic contribution to improve family welfare; 2) Increased knowledge and skills of women regarding the strategy of harmonizing roles in batik handicraft activities - batik business management with family - household management; 3) Increased knowledge and skills of women batik craftsmen regarding professionalism and management of entrepreneurship in handicrafts - batik businesses based on local wisdom. Conclusions: There was an increase in knowledge and awareness of women batik craftsmen about the strategic role of women, harmonization of women's roles and professionalism.

\section{A B S T R A K}

Latar belakang: Kontribusi ekonomi dari perempuan perajin batik Tuban relatif cukup penting dalam keluarganya walaupun pendapatan mereka dibawah upah minimum kabupaten/kota (dibawah UMK). Perempuan perajin batik Tuban pada umumnya bekerja sebagai pencari nafkah tambahan dengan jam kerja fleksibel dapat dikombinasikan dengan tugas domestik. Tujuan: Kegiatan ini bertujuan untuk memberikan solusi terhadap permasalahan; a) kerajinan dan usaha batik Tuban diperlakukan sebagai pekerjaan sampingan, bukan sebagai pekerjaan utama, sehingga tidak dikelola secara profesional dalam pengelolaan usahanya; b) perempuan perajin batik Tuban memilliki karakteristik sosial berpendidikan rendah dan seringkali hidup dalam kondisi miskin secara ekonomi sehingga berada pada posisi yang lemah dan rentan dari struktur sosial ekonomi; c) kesejahteraan kerja perempuan perajin batik Tuban tidak dilindungi secara formal karena produksi dan usaha batik berada pada lingkungan rumahan yang dianggap sebagai sektor informal; d) perempuan perajin batik Tuban harus berperan 'multi burden'. Metode: Kegiatan ini dilakukan dalam bentuk pelatihan dan pendampingan manajemen usaha. Hasil: Hasil dari kegiatan ini yaitu 1) Meningkatnya kesadaran perempuan perajin batik atas peran strategis mereka dalam kontribusi ekonomi untuk meningkatkan kesejahteraan keluarga; 2) Meningkatnya pengetahuan dan keterampilan perempuan tentang strategi harmonisasi peran dalam kegiatan kerajinan batik - pengelolaan usaha batik dengan pengelolaan keluarga - rumah tangga; 3) Meningkatnya pengetahuan dan keterampilan perempuan perajin batik tentang profesionalitas dan manajemen kewirausahaan kerajinan usaha batik yang berbasis pada kearifan lokal. Kesimpulan: Terjadi peningkatan pengetahuan dan kesadaran perempuan perajin batik tentang peran strategis perempuan, harmonisasi peran perempuan dan profesionalisme.

\section{Scope:}

Social-economic

\section{$A R T$ I CLE INFO}

Received 2 September 2020 Revised 5 September 2021 Accepted 20 October 2021 Online 10 November 2021

*Correspondence (Korespondensi): Karnaji

E-mail:

karnaji@fisip.unair.ac.id

Keywords:

Empowerment of Women; Batik craftsmen; Management; Entrepreneurship
Kata kunci:

Pemberdayaan Perempuan; Perajin Batik; Manajemen; Kewirausahaan 


\section{PENDAHULUAN}

Umumnya usaha batik banyak dilakukan oleh perempuan. Demikian juga dengan kerajinan Batik Tenun Gedog yang sebagian besar perajinnya merupakan perempuan. Kondisi ini memberikan gambaran bahwa, sektor ekonomi kreatif ini banyak menyerap tenaga kerja perempuan. Secara ekonomi memiliki peran strategis dalam memberdayakan perempuan melalui peningkatan ekonomi. Studi yang pernah dilakukan oleh Alfiani (2017), mengungkap bahwa perempuan pekerja rumahan seperti perajin batik kesejahteraan sosialnya cenderung tinggi karena terpenuhinya kebutuhan dasar sehari-hari. Hal tersebut dikarenakan para perempuan perajin batik bisa menggunakan pendapatnya untuk pemenuhan kebutuhan makan sehari-hari serta sebagian dari pendapatan dapat mereka tabung dengan cara ikut serta dalam arisar (Nawangsih, 2014).

Usaha Batik Tenun Gedog masuk dalam kategori sektor informal yang dalam pengelolaannya sangat fleksibel. Bisa digambarkan bahwa manajerial usaha ini masih sederhana dan konvensional dimana tenaga kerja biasanya sanak saudara maupun tetangga dekat yang tidak terikat. Mereka bisa bekerja kapan saja tanpa adanya batasan waktu. Bagi sebagian besar perempuan, pekerjaan membatik lebih dilihat sebagai pekerjaan sampingan.

Di Desa Gaji, Kecamatan Kerek, kesadaran akan besarnya potensi kerajinan batik dalam menggerakkan roda perekonomian masih sangat kurang. Usaha batik masih diperlakukan sebagai pekerjaan sambilan disela-sela waktu yang mereka miliki untuk melakukan pekerjaan pokok yaitu bertani. Akibatnya, usaha ini seringkali mengalami pasang surut. Pada musim panen, biasanya produktivitas menurun karena para perajin batik sibuk mengurus pertanian, sementara pada saat musim paceklik mereka baru kembali mengerjakan batik. Kondisi ini menyebabkan produksi tidak stabil dan kerapkali tidak dapat merespon permintaan pasar.

Disisi lain, berlakunya Masyarakat Ekonomi Asean (MEA) menjadikan persaingan usaha produk Usaha Mikro Kecil dan Menengah (UMKM) terutama kerajinan lokal semakin ketat karena pasar bebas mempermudah arus distribusi barang dari luar negeri. Hal ini tentunya membutuhkan kesiapan dari pelaku usaha Batik Tenun Gedog untuk bersaing dengan kompetitor internasional. Tidak hanya kualitas produk saja yang diperlukan dalam kompetisi global, kemampuan dalam manajemen kewirausahan juga menjadi syarat utama dalam persaingan tersebut guna menjamin kualitas, ketersediaan, pelayanan yang cepat serta keberlanjutan usaha.
Dari gambaran kondisi perajin batik dan para pelaku usaha batik gedog di Kecamatan Kerek, Tuban terlihat bahwa mereka mengalami kendala dalam melakukan manajemen wirausaha yang dijalani saat ini. Bagi mereka yang terpenting usaha masih bisa jalan tanpa disertai manajerial usaha yang profesional. Mengingat peran strategi kerajinan Batik Tenun Gedog bagi pengembangan ekonomi perempuan, maka pengabdian masyarakat ini bertujuan membantu mitra untuk melakukan pemberdayaan ekonomi perempuan dan memberikan pelatihan manajemen kewirausahaan pada perajin batik di Kecamatan Kerek. Tujuannya adalah menjaga eksistensi kerajinan batik sebagai penggerak roda perekonomian perempuan melalui pengelolaan usaha batik yang semakin profesional.

\section{METODE}

Metode yang dilakukan dalam kegiatan pengabdian masyarakat ini adalah dengan melakukan pelatihan kepada perempuan perajin batik di Kecamaan Kerek, Kabupaten Tuban yaitu: 1) Pelatihan Pendidikan peningkatan kesadaran peran strategis perempuan dalam kontribusi ekonomi untuk meningkatkan kesejahteraan keluarga; 2) Pelatihan peningkatan pengetahuan dan keterampilan perempuan tentang strategi harmonisasi peran dalam kegiatan kerajinan batik -pengelolaan usaha batik dengan pengelolaan keluarga-rumah tangga; dan 3) Pelatihan peningkatan pengetahuan dan keterampilan perempuan tentang profesionalitas dan manajemen kewirausahaan kerajinan - usaha batik yang berbasis pada kearifan lokal. Dengan adanya pelatihan tersebut para perempuan perajin batik diharapkan dapat meningkatkan kesadaranya terhadap peran strategis perempuan.

\section{HASIL DAN PEMBAHASAN}

Kegiatan pengabdian masyarakat yang dilakukan di Kecamatan Kerek Kabupaten Tuban pada para perajin batik diikuti antusias oleh kurang lebih 50 orang. Para peserta merupakan perempuan perajin batik Gedog yang selama ini masih kurang sejahtera. Kesejahteraan yang masih minim di kalangan para perajin batik perempuan tersebut karena adanya beberapa faktor yaitu: 1) kurangnya kesadaran perempuan perajin batik atas peran strategis mereka dalam kontribusi ekonomi untuk meningkatkan kesejahteraan keluarga; 2) kurangnya pengetahuan dan keterampilan perempuan perajin batik tentang profesionalitas dan manajemen kewirausahaan kerajinan-usaha batik yang berbasis pada kearifan lokal. 
Adanya permasalahan tersebut maka pengabdian masyarakat yang telah dilakukan bertujuan untuk: Pertama, meningkatkan kesadaran perempuan perajin batik atas peran strategis mereka dalam kontribusi ekonomi untuk meningkatkan kesejahteraan keluarga. Kedua, meningkatkan pengetahuan dan keterampilan perempuan tentang strategi harmonisasi peran dalam kegiatan kerajinan batik-pengelolaan usaha batik dengan pengelolaan keluarga - rumah tangga. Ketiga, meningkatkan pengetahuan dan keterampilan perempuan perajin batik tentang profesionalitas dan manajemen kewirausahaan kerajinan - usaha batik yang berbasis pada kearifan lokal. Untuk itu dalam kegiatan pengmas dilakukan beberapa pelatihan guna meningkatkan kesadaran akan posisi strategisnya dalam peningkatan perekonomian keluarga serta bagaimana bekerja secara profesional dan mengelola usaha kerajinan dengan manajemen yang baik dan benar.

Pelatihan manajemen usaha dimulai dengan memberikan wawasan kesadaran gender bagi para peserta. Adanya pelatihan tersebut selain memberikan pengetahuan kepada peserta tentang kesadaran gender juga meningkatkan kesadaran sebagai perempuan yang ternyata mereka memiliki potensi untuk turut berperan dalam peningkatan kesejahteraan keluarga melalui usaha produktif sebagai perajin batik. Selama ini, banyak perempuan yang tidak sadar bahwa mereka memiliki potensi dalam peningkatan kesejahteraan keluarga karena realitas tersebut seringkali terabaikan akibat dari hegemoni pembagian peran gender dimana perempuan identik dengan peran domestik. Sehingga, ketika perempuan bekerja rumahan seperti perajin batik, kontribusinya dalam peningkatan kesejahteraan keluarga tidak diperhitungkah (Agusmidah, 2018; Sofiani, 2012).

Pelatihan berikutnya merupakan pelatihan tentang bagaimana para perempuan perajin batik bisa bekerja profesional tanpa mengabaikan peranya sebagai ibu rumah tangga yang harus mengurus rumah, anak-anak dan suami (Qusminingrum, 2017). Hal tersebut penting untuk dilakukan karena tidak mudah bagi perempuan untuk menjalankan dua peran sekaligus yaitu peranya di sektor domestik dan publik. Dari hasil pengabdian yang dilakukan ternyata selama ini belum banyak perempuan yang bisa menjalankan dua peran tersebut. Rata-rata dari mereka masih menjadikan kegiatan membatik sebagai kegiatan sampingan untuk mengisi waktu luang. Konsekuensinya penghasilan yang mereka terima relatif minim serta tidak adanya posisi tawar untuk meminta upah lebih tinggi atas kerja yang dilakukan. Bias gender di masyarakat juga turut serta mempengaruhi penghargaan terhadap pekerjaan perempuan perajin batik sehingga usahanya tidak dihargai lebih oleh pemilik usaha (Suciptaningsih \& Sudrajat, 2016). Studi yang pernah dilakukan oleh Hendrarso (2009) mengungkapkan bahwa seringkali perempuan miskin juga tidak menyadari potensi yang dimiliki dan berpikir untuk masa depan karena kesibukan mereka dalam pemenuhan kebutuhan hidup sehari-hari. Disisi lain, para perempuan perajin batik yang menjadikan perajin batik sebagai profesi utama mereka juga kesulitan dalam menjalankan peran sebagai ibu rumah tangga yaitu mengurus anak, akibatnya anak-anak seringkali terabaikan atau kurang terurus.

Selanjutnya yaitu melatih perempuan perajin batik untuk bekerja profesional dan melakukan manajemen usaha dengan baik dan benar. Selama ini sebagian besar usaha yang dilakukan secara rumahan memang belum berjalan profesional dan memiliki manajemen yang baik. Seperti disinggung sebelumnya membatik bagi sebagian perempuan merupakan sampingan di sela-sala kesibukan mengurus rumah. Hal tersebut menjadikan para perajin batik rumahan ini kesulitan untuk memenuhi target pasar dan kalah bersaing dengan mereka yang telah profesional dimana mampu memenuhi target pasar serta pemasaran yang masif.

\section{KESIMPULAN DAN SARAN}

Pelaksanaan kegiatan pengabdian masyarakat Departemen Sosiologi Fakultas IImu Sosial dan IImu Politik Universitas Airlangga dengan judul "Upaya Pemberdayaan Ekonomi Perempuan dan Manajemen Kewirausahaan Pada Perajin Batik di Kecamatan Kerek, Kabupaten Tuban" bertujuan untuk meningkatkan kesejahteraan perempuan perajin batik. Hasil dari kegiatan tersebut, ternyata masih banyak perempuan para perajin batik yang selama ini tidak menyadari peran strategisnya dalam meningkatkan kesejahteraan keluarganya melalui usaha batik. Dari hasil kegiatan yang dilakukan, ada peningkatan pengetahuan dan kesadaran perempuan perajin batik tentang peran strategis perempuan, harmonisasi peran perempuan dan profesionalisme serta manajemen usaha kerajinan batik sebagai penyanggah perekonomian keluarga.

\section{UCAPAN TERIMA KASIH}

Kami mengucapkan banyak terima kasih kepada Universitas Airlangga yang telah memberikan pendanaan pada kegiatan pengabdian masyarakat ini. Terima kasih juga 
kami ucapkan kepada Pemerintah Kecamatan Kerek Kabupaten Tuban yang telah melaksanakan dan memfasilitasi kegiatan pengabdian kepada masyarakat. Penulis menyatakan tidak ada konflik kepentingan dengan pihak-pihak yang terkait dalam kegiatan pengabdian kepada masyarakat ini.

\section{DAFTAR PUSTAKA}

Agusmidah, 2018. Hak Ekonomi Perempuan: Pekerja Rumahan dalam Jangkauan UndangUndang Ketenagakerjaan. Talent. Conf. Ser. Local Wisdom, Soc. Arts Vol. 1(1), Pp. 1-7.

Alfiani, A.K., 2017. Kesejahteraan Sosial Pekerja Perempuan pada Industri Batik di Kecamatan Talun dalam Konteks Putting Out System. Skripsi. Yogyakarta: Universitas Gadjah Mada. Hendrarso, E.S., 2009. Perempuan miskin dan makna sosial kemiskinan. Masyarakat, Kebud. dan Polit. Vol. 22(4), Pp. 275-285.
Nawangsih, T., 2014. Peran Perempuan Pengrajin Batik dalam Peningkatan Kehidupan Sosial Ekonomi Keluarga (Studi kasus di Desa Pungsari, Plupuh, Sragen). Skripsi. Surakarta: Universitas Sebelas Maret.

Qusminingrum, A.W., 2017. Tindakan Voluntaristik Perempuan Dalam Menjalankan Peran Ganda (studi pada ibu rumah tangga pekerja rumahan dari Keluarga Prasejahtera di Kelurahan Polehan Kota Malang). Thesis. Universitas Muhammadiyah Malang.

Sofiani, T., 2012. Eksistensi Perempuan Pekerja Rumahan dalam Konstelasi Relasi Gender. MUWAZAH J. Kaji. Gend. Vol. 2(1), Pp. 197-204. Suciptaningsih, O.A., Sudrajat, R., 2016. Marginalisasi pada Perempuan Perajin Batik Gumelem. In: Seminar Nasional Hasil Penelitian 2016. Lembaga Penelitian dan Pengabdian Kepada Masyarakat, Semarang, hal. Pp. 269-279. 